\title{
Sağlık Çalışanlarının Tükenmişlik Düzeyleri ile Demografik Özellikleri Arasındaki İlişki -Samsun İli Örneği ${ }^{1}{ }^{1}$
}

\author{
Osman ÇEVİK ${ }^{2}$ ve Ahmet Alp ÖZBALCI ${ }^{3}$
}

Öz

Tükenmişlik, günümüz dünyasına adapte olma mücadelesi içinde yaşayanları ve her meslek grubundan çalışanları olumsuz yönde etkileyen bir durumdur. Sağlık çalışanları, çalışma ortamlarının doğası gereği yardıma ihtiyaç duyan kişilere sürekli ve kaliteli hizmet sunmak zorunda olduğu için diğer meslek gruplarına nazaran daha fazla mesleki tükenmişliğe maruz kalmaktadır. Bu sebeple, çalışmanın demografik yapısını oluşturan meslek grubu olarak sağlık çalışanları seçilmiştir. Sağlık çalışanlarının mesleki tükenmişlik açısından risk altında olduğu göz önünde bulundurularak oluşması muhtemel olumsuzlukların değerlendirilmesi yapılmış, tükenmişlik düzeylerinin ölçülmesi ve tükenmişlik düzeylerinin demografik açıdan farklılık oluşturup oluşturmadığı değerlendirilmiştir. Sağlık çalışanlarının tükenmişlik düzeyleri ile demografik özellikleri arasındaki ilişkiyi araştırmayı amaçlayan bu çalışma, Mart 2019 tarihinde Samsun ilinde sağlık hizmeti sunan beş kamu hastanesinde çalışmakta olan personel üzerinde yapılmıştır. Gerçekleştirilen anket uygulamasında formun dağıtıldığı sağlık çalışanlarının 449’undan geri dönüş alınmıştır. Araştırmada, örneklem grubunu oluşturan sağlık çalışanlarının demografik ve çalıştıkları sağlık kurumlarına ilişkin özellikleri frekans ve yüzde dağılımları şeklinde verilmiştir. Araştırmadan elde edilen bulgular neticesinde ankete katılan sağlık çalışanlarının tükenmişlik düzeylerine cinsiyet, çocuk sayısı ve istihdam şekli faktörlerinin etki etmediği, bunun yanında yaş, eğitim düzeyi, medeni durum, meslekteki toplam görev süresi, kurumdaki toplam görev süresi ve kurumdaki pozisyonu faktörlerinin ise etkilediği saptanmıştır. Bireysel değişkenlerin tükenmişlik düzeyine olan etkisi değerlendirildiğinde çalışanlar arasında tükenmişlik sendromunun bulunduğu ve orta seviyede olduğu görülmüştür.

Anabtar Kelimeler: Tükenmişlik, Sağlık, Sağlık çalışanları, Demografi, Samsun

\section{The Relationship between Burnout Levels and Demographic Characteristics of Health} Workers: The Case of Samsun

\begin{abstract}
Burnout is a situation that adversely affects those struggling to adapt to today's world and all occupational group workers. Due to the nature of their working environment, health workers are exposed to more occupational burnout than other groups because they have to provide continuous and quality service to people in need of assistance. For this reason, health professionals were selected as the occupational group that constitutes the demographic structure of the study. Considering that health workers are at risk in terms of occupational burnout, possible negativities that may occur were evaluated, measuring burnout levels and determining whether burnout levels made demographic differences. This study was conducted on staff working in five public hospitals in Samsun in March 2019. In the survey, 449 of the health care workers to whom the form was distributed provided feedback. In the study, the demographic characteristics of the health care workers in the sample group and the characteristics of the health institutions they work for were given as frequency and percentage distributions. As a result of the findings obtained from the research, it was found that the factors of gender, number of children and employment type did not affect the burnout levels of the health workers participating in the survey. On the other hand, age, education level, marital status, total term of duty in the profession, total term of duty in the institution and position in the institution were found to affect the burnout level of the employees. When the effect of individual variables on burnout level is evaluated, it is seen that burnout syndrome is present among the employees and it is moderate.
\end{abstract}

Key Words: Burnout, Health, Health workers, Demography, Samsun

\section{Atıf İçin / Please Cite As:}

Çevik, O. ve Özbalcı, A. A. (2020). Sağlık çalışanlarının tükenmişlik düzeyleri ile demografik özellikleri arasındaki ilişki -Samsun ili örneği. Manas Sosyal Araștırmalar Dergisi, 9(3), 1773-1787.

Geliş Tarihi / Received Date: 25.12.2019

Kabul Tarihi / Accepted Date: 04.03.2020

\footnotetext{
${ }^{1}$ Bu çalışma "Sağlık Çalışanlarının Tükenmişlik Düzeyi İle Bilişim Sistemindeki Değişimlere Karşı Gösterdikleri Direnç Arasındaki İlişki: Samsun İli Örneği" başlıklı doktora tez çalışması kapsamında (tez savunmasından önce) tezden kısmen yararlanılarak hazırlanmıștır.

2 Prof. Dr. - Karamanoğlu Mehmetbey Üniversitesi - İ̈BF osmancevik@kmu.edu.tr - ORCID: 0000-0002-2217-8876

3 Öğr. Gör. - Karamanoğlu Mehmetbey Üniversitesi - SBE - aalp.ozbalci@samsun.edu.tr - ORCID: 0000-0002-9539-844X
} 


\section{Giriş}

Bireyin hayatın her anında yüzleşmekte olduğu sıkıntılar, değişen ve gelişen teknolojinin de etkisi ile ivme kazanarak bireyin dengesini her anlamda bozabilmektedir. Birey, çalışan sıfatıyla emek sarf ettiği iş hayatı içerisinde mesleğin kendine has anlam ve amaçlarının doğurduğu zorluklarla başa çıkarken diğer yandan işinin gerekliliklerine uygun olan performansı sergilemek mecburiyetindedir. Birey, iş hayatındaki sorumluluklarında farklılaşma ve iş yükünün artışı gibi nedenlerden dolayı öncelikli olarak günlük hayatında zorluklarla karşılaşmaktadır. Bu zorluklar zamanla daha da ciddileşerek iş hayatını tehdit eder bir hâle gelmektedir. Bireyin yaşamış olduğu bu durum, hizmet sağladığ1 diğer insanlara karş̣ davranışlarında duyarsız bir ruh hâline bürünmesine, psikolojik açıdan yıpranmışılı hissine kapılmasına ve tüm bunların etkisi ile kendini başarısız hissetmesine neden olmaktadır. Zorluklar karşısında ruhsal olarak aşırı stres altında olan çalışanlar, bu sorunu çözme amacı ile stresle mücadeleyi öğrenmekte ya da strese yenik düşerek stresin neden olduğu tükenme hâliyle karşı karşıya kalmaktadır.

Tükenme hâli, özellikle direkt olarak insana hizmet sunan ve yapılan işin kalitesinin insanî faktörlerle doğru orantılı olduğu mesleki alanlarda görülmektedir. Günümüz modernleşen toplumuna adapte olmaya çalşan bireyin, hangi demografik özelliklere sahip olursa olsun tükenmişliği belli oranlarda yaşama ihtimali bulunmakta olup bu ihtimal hızla artış göstermektedir. Yapılan araştırmalar sonucunda tükenmişlik duygusu; bireyin performansını, mesleki ve iş tatminini, hizmetin kaliteli sunumunu ve işten bağlllıklarını olumsuz yönde etkileyen faktör olarak saptanmıştır. Bu duygu; özellikle sağlık çalışanları, turizmciler, bankacılar, öğretmenler ve benzeri meslek gruplarında yaygın olarak görülmektedir. (Kozak, 2001, s. 11).

Tükenmişlik, bir hastalık olarak kabul edilmiş olsa da bireyin bu duruma ilişkin bağışılık geliştiremediği ve tedavi edilmesi hâlinde dahi tekrarlaması muhtemel bir durumdur. Modernleșen dünyanın da etkisi ile son zamanlarda yaygınlaşan tükenmişlik, çalışanların genelinde ve iş hayatının herhangi bir evresinde karşılaşılan bir sendromdur. Tükenmişlik, aniden ortaya çıkan akut bir durum değil, zamanla ve derinden gelişen sonrasında ise bireyin psikolojik dengesini etkileyen bir ruh hâli olarak değerlendirilebilir. Bireyin ruhsal yapısındaki bu olumsuzluk hâli zamanla iş, aile ve özel hayatında da problemlerin ortaya çıkmasına yol açmaktadır. Aşırı yoğun, zaman kısıtlaması olan, aniden gelişen, dikkat gerektiren, ayrıntının önemli olduğu ve beklenmedik durumlara açık olan mesleklerde çalışan bireylerin tükenmişlik sendromunu yaşaması muhtemeldir. Buradan hareketle birey, iş tanımı ne olursa olsun farklı seviyelerde tükenmişlik hastalı̆ına yatkındır(Hsu ve Marshall, 1980)

Sağlık çalışanlarının hizmet sunumunun merkezinde insan vardır ve insan işinin her anında farklı demografik yapıdaki diğer insanlarla sürekli iletişimdedir. Bu durum; çalışan üzerinde bask1 ve stres kaynaklı olumsuz bir durum oluşturmaktadır, çalsşanın enerjisinin tükenmesine ve son noktada da tükenmişlik hâline neden olmaktadır (Borkowski, 2005). Sağlık çalışanlarının iş hayatı içerisinde yaşadıkları tüm olumsuzluklar kendisinden ve görevli olduğu kurumdan önce, sağlık hizmeti sunduğu diğer insanları kötü yönde etkilemektedir. Bahsedilen hassas durumdan dolayı bu çalı̧̧mada, kamu hastanelerinde görev yapmakta olan sağlık çalışanlarının tükenmişlik düzeylerinin analizi yapılmıştır.

\section{Tükenmişlik Kavramı}

Tükenmişlik, bir araştırma alanı olarak kabul edilmeden önce sosyal bir sorun olarak görülmüştür. Genel itibari ile kavram üzerine fikir beyan edenlerin ortaya koyduğu tanımlar benzerlik gösterir nitelikte olsa da ifade edilişi bakımından farklılıklar göstermektedir. Kavram üzerine yapılan araştırmaların boyutları ve çeşitliliği genişledikçe bu durum tükenmişlik kavramının ve işlevinin ortaya koyulması noktasında tartışmalara neden olmuştur (Çapri, 2006, s. 63).

İlk kez 1974 yılında psikolog Herbert J. Freudenberger tarafindan "Staff BurnOut" adlı makalesinde tükenmişlik, "kişinin yaşam enerjinin tükenmesi, başkalarının aşıı talep ve sorunlarının altında ezilerek bunalma hâlinin başlaması durumudur" şeklinde dile getirilmiştir (Aşan ve Aydın, 2006, s. 240). Bu tanımlamadan sonra, duygusal tükenme hâlinin bir hastalık olduğu kabul edilmiş ve 1997'de İsveç'te hastalık tanısı konularak tescillenmiştir (Friberg, 2009, s. 538).

Tükenmişlik üzerine yapılan araştırmaların genelinde Cristina Maslach'ın fikirleri kabul görmektedir. İnsanlarla iletişim içinde olan meslek grubu çalısanlarıyla bu kapsamda görüşme yapan ilk araştırmacı Maslach'tır. Maslach, teorisi olmadan binlerce insandan veriler toplamıştır (Çağlıyan, 2007, s. 15). Maslach; bu çalışmaların bir sonucu olarak tükenmişliği, çalışma hayatı içerisinde bireyin dengesinin bozulmasına neden olan ve kronikleşen olumsuzluklar ve oluşan strese karşı bir tepki olarak tanımlamaktadır. 
Tükenmişlik kavramı, Maslach ve diğer araştırmacılar tarafindan boyutsal ve işlevsel olarak sonraki çalışmalarında güncellenerek "bireysel olarak aynı kapasitede çalışan kişilerin kişisel başarısının azalması, duygusal tükenmişlik ve benlik yitimi olarak ortaya çıkan bir sendrom" şeklinde ele alınmıştır (Maslach, Jackson ve Leiter, 1996). İlerleyen dönemlerde Maslach, sade bir ifade ile tükenmişliği "çalışma ortamında oluşan ve kronik hâle gelen kişisel, duygusal stres" olarak dile getirmiştir (Maslach, 2003, s. 190). Tükenmişlik kavramının ortaya atıldığı 1974 yılından bu zamana kadar kavrama ilişkin farklı ifadeler kullanılmış olsa da yapılan araştırmalarda genel olarak Maslach ve Jackson'ın (1981) tükenmişlik modeli kabul görmektedir. Freudenberger, tükenmişliği sadece duygusal bir olumsuzluk hâli olarak kabul ederek bu yönü ile ilgilenmiş olsa da Maslach ve Jackson (1986) tükenmişliğin üç alt boyuttan oluştuğunu ve bu yönleri ile ele alınması gerektiğini belirtmektedir. Duygusal olarak tükenme hâli tek başına tükenmişlik kavramını karşılamamakta, aynı zamanda olaylar karşısında tepkisiz kalma hâlini ve bireyin başarı seviyesinin de düşmesi durumunu belirtmektedir (Sağlam ve Bal, 2008, s. 132). Bu model; duygusal tükenme, duyarsızlaşma artışı ve kişisel başarı eksikliği duygusunda azalma olmak üzere üç alt faktörden oluşmaktadır (Kırılmaz vd., 2003: 2-9). Konu ile ilgili araştırmaların genelinde Christina Maslach tarafından oluşturulan "Maslach tükenmişlik ölçeği”nden yararlanılmaktadır. Ölçek, araştırmacılar tarafindan kabul gören duygusal tükenme, duyarsızlaşma ve kişisel başarının azalması boyutlarını kapsamaktadır (Maslach, Schaufeli ve Leiter, 2001, s. 397). Bu bağlamda, tükenmişlik kavramının üç alt boyuta sahip sendrom olarak kompleks bir yapıda değerlendirilmesi gerekmektedir (Gürses, 2006, s. 11).

Maslach tükenmişlik sendromunda birey, enerjisi azalan ve duygusal kaynaklarının tükendiği hissine kapılarak hizmet sunduğu insanlara ve mesleğine karşı soğuk, ilgisiz hatta insanlık dışı tutum sergileyerek kendini yetersiz ve başarısız olarak kabul etmektedir. Bu tutum çerçevesinde bireyi değerlendiren Maslach, ortaya koymuş olduğu model ile duygusal tükenme, duyarsılaş̧ma ve kişisel başarı eksikliği alt boyutları hakkında değerlendirmelerde bulunmuştur (Maslach ve Jackson, 1981, s. 102).

Tükenmişlik, kişiden kişiye farklı belirtileri ve seviyesi olan bir durum olduğu için nedenlerinin de ayrı ayrı ele alınması gerekmektedir. Ancak yapılan araştırmaların genelinde tükenmişliğin nedenleri bireysel ve örgütsel olmak üzere iki ana başlık altında toplanmıştır. Kişilik özellikleri ve bireyin işe karşı tutumu ile ilgili faktörleri; cinsiyet, medeni durum, çocuk sayısı, yaş, eğitim durumu, çalışma süresi, pozisyonu vb. durumlar bireysel özellikler olarak kabul edilmektedir. Diğer taraftan; çalışma ortamı, çalışma sistemi, örgüt yapısı, işin özellikleri, işin niteliği, işin ağırlığı, yönetim şekli, ödül-ceza uygulamaları, örgüt içi adalet gibi durumları ise örgütsel özellikler olarak sıralamak mümkündür (Maslach vd. 2001, s. 407 - 411). Genel bir ifade ile kişi özelinde ve örgüt yapısındaki durumlar, her birey için farkll1ık göstermektedir. Bu farklılık sebebiyle bireyler farklı seviyelerde etkilenmekte ve tükenmişliğin tespitinin çok yönlü olarak ele alınması gerekmektedir.

Tükenmişlik sendromuyla farklı seviye ve belirtilerde karşılaşılmaktadır. Bireyin tükenmişlik seviyesini hafif, orta ve şiddetli olarak sınıflandırmak mümkündür. Birey her seviyede farklı davranış ve tutumda olabilirken değişik belirtiler gösterebilmektedir. Başlangıç seviyesi olan hafif dönemde kişi geçici huzursuzluk hâlinde, enerjisi azalmış olarak kendini yorgun hissetme gibi belirtiler gösterebilir. Tükenmişliğin bir sonraki seviyesi olan orta dönemde ise bireyin ilk dönemdeki belirtileri daha kuvvetli yaşadığı gözlemlenmektedir. Son seviye olan şiddetli tükenme evresine gelindiğinde ise ruhsal yapıdaki semptomlara ek olarak sağlığ1 tehdit eden fiziksel problemler ortaya çıkmaktadır (Özgüven, 2003, s. 239). Tükenmişlik sinsi ve derinden gelen bir süreçtir. Tükenmişlik semptomlarının bireyin oluşan stresi ve olumsuzlukları algılamasındaki farklılıktan kaynaklanabileceği düşünülmektedir (Beemsterboer ve Baum, 1984).

Bireyin tükenmişlik hâlini yukarıda belirtilen semptomlara göre değerlendirmek mümkün olmakla beraber kişide yaşanması muhtemel belirtileri göz ardı etmemek gerekmektedir. Tükenmişliğin belirtilerini fiziksel, duygusal ve zihinsel olmak üzere üç grupta ele almak gerekmektedir. Bireyde fiziksel olarak; enerji kayb1 ve güçsüzlük, aşırı yorgunluk ve bitkin hissetme, baş-boyun-bel ağrısı, migren, uykusuzluk, solunum güçlüğü, kas krampları ve hastalıklara karşı bağışıklı̆̆ın zayıflaması gibi belirtiler gözlenmektedir. Duygusal olarak; çaresizlik hissi, öfke, kızgınlık, sabırsızlık, huzursuzluk gibi negatif duyguların artışı, insanî davranışlarda azalma, saygısız, nezaketsiz bir hâle bürünme, şüpheci ve endişeli bir kişilik yapısı, alınganlık, kötü alışkanlıklara karşı eğilim, aile başta olmak üzere insanlardan uzaklaşma, içe kapanma, ağlama, teslimiyet, suçluluk duygusu ve işten ayrılma, pes etme gibi belirtiler gözlenmektedir. Zihinsel olarak; unutkanlık, odaklanama, yaratıclık kaybı, konfüzyon, çalışma veriminde eksilme ve değişime direnç gibi belirtiler gözlenmektedir (Süloğlu, 2009, s. 14). 
Tükenmişlik nedenleri ve belirtileri ile çalışma hayatında sıklıkla karşılaşılan bir olgudur. Tükenmişliğin tespitinde kullanılan yöntemlerin genelinde önemli olan kişisel değişkenlerin ve örgütsel etkenlerin belirlenmesidir. Aynı çalışma ortamını paylaşan bireylerde tükenmişlik farklı seviyelerde yaşanabilir. Bu bireylerin tükenmişlik nedenlerini ve seviyelerini tespit etmek amacıyla yapılan çalışmalarda kişisel değişkenlere dikkat edilmesi gerekmektedir. Stres ve sosyal açıdan olumsuzluk kaynağı olan bir çalışma ortamının farklı demografik yapıdaki bireyler üzerine etkisini gözlemlemek önemlidir. Tükenmişlik seviyesi ile demografik özellikler arasındaki ilişki bu şekilde tespit edilebilmektedir. Sürgevil’e (2005) göre; kötü birey veya çalışanın belirlenmesi konusuna odaklanarak kısır döngüye girmek yerine, olumsuz çalışma ortamlarındaki işlevsel ve yapısal özellikleri ortaya koymak gerekmektedir.

\section{Yöntem}

Bu çalışmada, kamuya bağlı hastanelerde görev yapmakta olan sağlık çalışanlarının tükenmişlik düzeylerinin ölçülmesi ve tükenmişlik düzeylerinin demografik açıdan farklılık oluşturup oluşturmadığının belirlenmesi amaçlanmaktadır.

Araştırma 2019 yllını Mart ayında, Samsun ilinde sağlık hizmetinde bulunan beş kamu hastanesinde çalısmakta olan personel üzerinde yapılmıştır. Sözü edilen kamu hastanelerinde görev yapmakta olan toplam 5215 sağlık çalışanı araştırmanın evrenini oluşturmaktadır. Ancak sözü edilen evrenden araştırmanın büyüklüğü değerlendirildiğinde sağlık çalışanlarının iş yoğunluğu, zaman kısıtlılığ ve sorumluluklarının fazla olması gibi nedenlerle doktor, diş hekimi, psikolog gibi personel kapsam dışında bırakılmıştır. Tüm evreni \% 95 güven aralığında temsil edebilecek örneklem büyüklüğ̈̈ 358 personel olarak hesaplanmıştır. Sözü edilen sağlık kurumlarında görev yapan ve araştırma kısıtlarına uygun olarak belirlenen personel, üç ana unvan sınıfinda gruplandırılmıştır. Gruplar, "hemşire-ebe sınıfi", "genel sağlık hizmetleri sınıfi", "genel idari hizmetler sınıfı" olarak adlandırılmıştır. Bu çerçevede beş kamu hastanesinde gerçekleştirilen anket uygulamasında anket formunun dağıtıldığ1 449 sağlık çalışanından geri dönüş alınmıştır.

Çalışmada veri toplama aracı olarak anket kullanılmış olup anket formunun ilk bölümünde katılımcıların demografik özellikleri (cinsiyet, yaş, eğitim durumu, medeni durum, çocuk sayısı, istihdam şekli, meslekte toplam çalışma süresi, kurumdaki toplam çalışma süresi ve sağlık kurumundaki pozisyonu) yer almaktadır. Anket formunun ikinci bölümünde Maslach tarafindan oluşturulan ölçekten faydalanılmıştır. Tükenmişlik düzeyini belirlemek için, Maslach tarafından geliştirilen, ülkemiz için geçerlilik ve güvenirlik çalışması Çam $(1991)$ ve Ergin $(1993,1996)$ tarafından yapılmış olan "Maslach tükenmişlik ölçeği” (MTÖ) kullanılmışır (Dikmetaş, Top ve Ergin, 2011). Ölçek yirmi iki ifadeden ve üç alt boyuttan (duygusal tükenme, kişisel başarı eksikliği ve duyarsızlaşma) oluşmaktadır.

Veriler; bilgisayar ortamında istatistik yazılım programı aracilığıla analiz edilmiştir. Araştırmada, örneklem grubunu oluşturan sağlık çalışanlarının demografik ve çalıştıkları sağlık kurumlarına ilişkin özellikleri frekans ve yüzde dağılımları şeklinde verilmiştir. Araştırmada hem verilerin normal dağılımına hem de homojenliğine ilişkin uygun testler yapılmış olup p değerlerinin 0,05 'ten büyük olduğu tespit edilmiştir. Dolayısıyla belirlenen tüm varsayımlar araştırmada gerçekleştiği için tükenmişlik ölçeğine ait alt boyutların karşılaştırılması amacı ile ilişkili ölçümler için (for dependent/repeated measures) varyans analizi kullanılmıştır. Varyans analizi sonucunda farklılık bulunması durumunda tükenmişlik ölçeği alt boyutlarının ilişkili ölçümler için ikili ölçümün karşılaştırılmasında çoklu karşılaş̧ırma testlerinden Bonferroni testinden yararlanılmıştır. Bununla birlikte, sağılk çalışanlarının tükenmişlik düzeyleri ile bireysel özelliklere göre karşılaştırılmasında (iki grup için) bağımsız örneklemler için $t$ testi (independent samples $t$ test) ve (ikiden fazla grup için) tek yönlü varyans analizi (one way ANOVA) kullanılmıştır. Varyans analizi sonucunda farklılık bulunan grupların ikili olarak karşılaştırlmasında ise Tukey testinden yararlanılmıştır.

Diğer taraftan, ölçme aracı olarak kullanılan ankette yer alan tükenmişlik ölçeğinin yap1 geçerliğine ilişkin varimax rotasyonu ve temel bileşenler (principal components) yöntemi kullanılarak faktör analizi uygulanmıştır. Faktör analizinin uygulanabilirliği Bartlett testi, örneklem hacminin yeterliği ise KaiserMeyer-Olkin (KMO) değeri ile kontrol edilmiştir. Ayrıca, ölçeklerin iç tutarlığına yönelik güvenirlik analizi için Cronbach's Alpha değerleri hesaplanmış ve elde edilen veriler çalışmanın bulgular bölümünde verilmiştir. 


\section{Bulgular}

Araştırmanın bu kısmında, Samsun ili sınırlanı içerisinde sağlık hizmeti sunan kamu hastanelerinde görevli sağlık çalışanlarının tanımlayıcı özelliklerine göre kullanılan ölçeğin geçerlik ve güvenirliği, katılımcıların tanımlayıcı özellikleri, tükenmişlik düzeyleri, tükenmişlik ölçeği ile tanımlayıcı özelliklerinin ilişkisine yönelik bulgular yer almaktadır.

\section{Geçerlik ve Güvenirliğine İlişkin Bulgular}

Araştırmada tükenmişlik düzeyini tespit etmek amacı ile kullanılan ölçeğin geçerlik ve güvenirliğine yönelik bulgular Tablo 1'de sunulmuştur.

Tablo 1. Tükenmislik Ölçę̆ine Ilişkin Faktör Analiæi ve Güvenirlik Analiæi Sonuclar

\begin{tabular}{lccc}
\hline \multirow{2}{*}{ İfadeler } & $\begin{array}{c}\text { Faktör 1 } \\
\text { Duygusal Tükenme }\end{array}$ & $\begin{array}{c}\text { Faktör 2 } \\
\text { Kişisel Başar1 }\end{array}$ & $\begin{array}{c}\text { Faktör 3 } \\
\text { Duyarsızlaşma }\end{array}$ \\
\hline Özdeğerler (eigenvalues) & 5,518 & 3,985 & 2,945 \\
Varyans1 açılklama oranı & 25,084 & 18,113 & 13,385 \\
Kümülatif varyans & 25,084 & 43,197 & 56,582 \\
Alt Boyut Güvenirliği (Cronbach's Alpha) & 0,914 & 0,850 & 0,800 \\
\hline Genel Ölçek Güvenirliği (Cronbach's Alpha) & & $\mathbf{0 , 8 2 9}$ & \\
\hline \multirow{2}{*}{ Kaiser-Meyer-Olkin (KMO)=0,901 Bartlett testi: $\chi 2=4833,968 ;$} & \multirow{2}{*}{$\mathrm{P}=0,000$}
\end{tabular}

Tablo 1'deki faktör analizi sonuçlarına göre, Kaiser-Meyer-Olkin değeri örneklem hacminin yeterliğini $(\mathrm{KMO}=0,901)$, Bartlett testi ise faktör analizinin uygulanabilirliğini $\left(\chi^{2}=4833,968 ; \mathrm{P}<0,001\right)$ ortaya koymuştur.

Ölçekteki duygusal tükenme alt boyutu, toplam varyansın \% 25,084’ünü açıklayan ilk faktör olmuştur. İkinci faktör olan kişisel başarı eksikliği boyutu toplam varyansın \% 18,113'ünü açıklayan alt boyut olarak belirlenmiştir. Üçüncü faktör olan duyarsızlaşma boyutu toplam varyansın \% 13,385'ini açıklamaktadır. Bu noktada, tükenmişlik ölçeği için genel güvenirlik katsayısı Cronbach's Alpha $\alpha=0,829$ olarak hesaplanmış olup bu ölçeği oluşturan 3 alt boyut için de Cronbach's Alpha katsayılarının tamamı $\alpha=0,70$ 'in üzerinde olduğundan, güvenilir olduğu görülmektedir.

\section{Bireysel Özelliklere İlişkin Bulgular}

Örneklem grubunu oluşturan sağlık çalşsanlarının demografik bilgilerini içeren değişkenlere ait frekans ve yüzde dağılımları hesaplanmıştır.

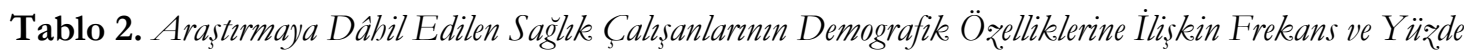
Dağıllamları $(n=449)$

\begin{tabular}{|c|c|c|c|c|c|c|c|}
\hline Değişkenler & Gruplar & $\mathrm{f}$ & $\%$ & Değişkenler & Gruplar & $f$ & $\%$ \\
\hline \multirow{2}{*}{ Cinsiyet } & Kadın & 311 & 69,3 & \multirow{2}{*}{ İstihdam Şekli } & Memur & 343 & 76,4 \\
\hline & Erkek & 138 & 30,7 & & Sözleşmeli & 106 & 23,6 \\
\hline \multirow{4}{*}{ Yaş } & 25 yaş ve alt1 & 17 & 3,8 & \multirow{6}{*}{$\begin{array}{l}\text { Meslekteki Toplam } \\
\text { Görev Süresi }\end{array}$} & 1 ylldan az & 12 & 2,7 \\
\hline & $26-34$ yaş & 161 & 35,9 & & $1-5 \mathrm{yll}$ & 36 & 8,0 \\
\hline & $35-44$ yaş & 196 & 43,7 & & $6-10 \mathrm{yll}$ & 126 & 28,1 \\
\hline & 45 yaş ve üzeri & 75 & 16,7 & & $11-15$ yll & 133 & 29,6 \\
\hline \multirow{4}{*}{ Eŭitim Düzeyi } & Lise & 57 & 12,7 & & $16-20 \mathrm{yil}$ & 60 & 13,4 \\
\hline & Ön Lisans & 90 & 20,0 & & 20 yıldan fazla & 82 & 18,3 \\
\hline & Lisans & 287 & 63,9 & \multirow{6}{*}{$\begin{array}{l}\text { Kurumdaki Görev } \\
\text { Süresi }\end{array}$} & 1 yildan az & 53 & 11,8 \\
\hline & Lisansüstü & 15 & 3,3 & & $1-5 \mathrm{y} 1 \mathrm{l}$ & 86 & 19,2 \\
\hline & Evli & 350 & 78,0 & & $6-10 \mathrm{yll}$ & 146 & 32,5 \\
\hline Medeni Durum & Bekâr & 99 & 22,0 & & $11-15 \mathrm{yll}$ & 81 & 18,0 \\
\hline \multirow{6}{*}{ Çocuk Sayısı } & Yok & 105 & 23,4 & & $16-20 \mathrm{yil}$ & 44 & 9,8 \\
\hline & 1 & 103 & 22,9 & & 20 yildan fazla & 39 & 8,7 \\
\hline & 2 & 194 & 43,2 & \multirow{4}{*}{$\begin{array}{l}\text { Kurumdaki } \\
\text { Pozisyonu }\end{array}$} & \multirow{2}{*}{ Ebe-Hemşire } & \multirow{2}{*}{215} & \multirow{2}{*}{47,9} \\
\hline & 3 ve daha fazla & 47 & 10,5 & & & & \\
\hline & & & & & $\begin{array}{l}\text { Sağllk Hizmetleri } \\
\text { Sinıfi }\end{array}$ & 119 & 26,5 \\
\hline & & & & & $\begin{array}{l}\text { Genel İdari } \\
\text { Hizmetler Sınıfi }\end{array}$ & 115 & 25,6 \\
\hline
\end{tabular}


Araştırmaya katılan sağlık çalışanlarının demografik özellikleri Tablo 2'de gösterilmekte olup dağılıma göre, katılanların \% 69,3’ü (f=311) kadın çalışanlardan oluşmaktadır. Yaşlarına göre dağılım incelendiğinde, $\%$ 43,7'sinin ( $\mathrm{f}=196$ ) 35-44 yaş aralığında olduğu, yine çalışanların \% 78'inin medeni durumunun evli olduğu ve katılımcıların \% 23,4’ünün çocuğunun olmadığ1 geri kalan kesiminde ise en az bir tane çocuk sahibi olduğu görülmektedir.

Çalışanlar, eğitim seviyelerine göre değerlendirildiğinde \% 63,9’luk (f=287) oran ile lisans mezunlarının daha yoğun olduğu ve \% 76,4’lük bölümünün ise memur statüsünde istihdam edildiği görülmektedir. Çalışanlar, meslekteki toplam görev süreleri bakımından ele alındığında \% 29,6’lık oran ile 11-15 y1l arasında görev yapan personelin yoğunlukta olduğu, mevcut kurumda görev yapma süresi bakımından değerlendirildiğinde ise \% 32'lik oran ile 6-10 y1l arasında çalışma süresi olan çalışanların ağırlıkta olduğu saptanmıştır. Ayrıca kurumdaki pozisyonu ebe-hemşire statüsünde olanların sayısı 215 olup tüm katılımciların \%47,9’luk oranını temsil etmektedir.

\section{Tükenmişlik Ölçeğine Yönelik Bulgular}

Tablo 3. Tükenmişlike Ölçeğindeki Boyutlarm Karşılaştırlmasına Yönelik İstatistikler

\begin{tabular}{llllc}
\hline \multicolumn{1}{c}{ Tükenmişlik Ölçeğindeki Boyutları } & $\overline{\mathrm{X}}$ & S.S. & F & P \\
\hline Duygusal Tükenme & $2,76 \mathrm{a}$ & 0,84 & 233,873 & $0,000^{*}$ \\
Kişisel Başarı & $3,39 \mathrm{a}$ & 0,70 & & \\
Duyarsızlaşma & $2,19 \mathrm{~b}$ & 0,86 & & \\
\hline
\end{tabular}

Tablo 3'te tükenmişlik ölçeğindeki boyutların karşılaştırılması amacıyla tek-faktörlü varyans analizi ve farklılığın hangi alt boyutlar arasında gerçekleştiğini ortaya koymak için gerçekleştirilen "Bonferroni” testi sonuçları sunulmuştur. Buna göre tükenmişlik ölçeğine ait ortalamalar arasında anlamlı bir farklılık tespit edilmiştir (P<0,001). Aritmetik ortalama değerlerine göre araştırmanın örneklem grubundaki sağlık çalışanlarının diğer boyutlara göre en çok kişisel başarı eksikliği $(\overline{\mathrm{x}}=3,39)$ boyutunu benimserken, orta düzeyde duygusal tükenme $(\bar{x}=2,76)$ boyutunu ve en az düzeyde duyarsılassma $(\bar{x}=2,19)$ boyutunu benimsedikleri görülmüştür.

\section{Tükenmişlik Ölçeğindeki Alt Boyutlar ile Bireysel Özelliklerin İlişkisine Yönelik Bulgular}

Araştırma kapsamında yer alan sağlık çalışanlarının tükenmişlik ölçeğindeki alt boyutlarının tanımlayıcı özelliklere göre karşılaştırılmasına yönelik; $t$ testi (independent samples $t$ test), varyans analizi (one way ANOVA) ve Tukey HSD-Analizi yapılmıştır.

Tablo 4. Tükenmişlik Ölçeğindeki Alt Boyutlarn Cinsiyete Göre Karşılaşttrılması

\begin{tabular}{llllcc}
\hline Tükenmişlik Ölçeğindeki Boyutları & Cinsiyet & $\overline{\mathrm{X}}$ & S.S. & $\mathbf{t}$ & $\mathbf{P}$ \\
\hline \multirow{2}{*}{ Duygusal Tükenme } & Erkek & 2,64 & 0,78 & 1,852 & 0,065 \\
& Kadın & 2,80 & 0,86 & & \\
\hline \multirow{2}{*}{ Kişisel Başarı Eksikliği } & Erkek & 3,42 & 0,73 & $-0,652$ & 0,515 \\
\hline \multirow{2}{*}{ Duyarsızlaşma } & Kadın & 3,37 & 0,69 & & 0,253 \\
& Erkek & 2,26 & 0,91 & $-1,144$ & \\
\hline
\end{tabular}

Tablo 4'te yer alan t testi sonuçlarına göre, duygusal tükenme ( $\mathrm{P}=0,065 ; \mathrm{P}>0,05)$, kişisel başarı eksikliği $(\mathrm{P}=0,515 ; \mathrm{P}>0,05)$ ve duyarsızlaşma $(\mathrm{P}=0,253 ; \mathrm{P}>0,05)$ alt boyutlarında cinsiyetlere göre anlamlı farklılıklar tespit edilememiştir.

Tablo 5. Tükenmişlik Ölçeğindeki Boyutlarm Yaşlara Göre Karşılaştırlması

\begin{tabular}{|c|c|c|c|c|c|c|}
\hline $\begin{array}{c}\text { Tükenmişlik Ölçeğindeki } \\
\text { Boyutları }\end{array}$ & $\begin{array}{l}\text { Meslekteki Toplam } \\
\text { Görev Süresi }\end{array}$ & $\bar{X}$ & s.s. & $\mathbf{F}$ & $\mathbf{P}$ & Tukey \\
\hline \multirow{4}{*}{ Duygusal Tükenme } & 25 yaş ve altı & 2,88 & 0,64 & 3,803 & $0,010^{*}$ & $1-4$ \\
\hline & $26-34$ yaş & 2,74 & 0,85 & & & \\
\hline & $35-44$ yaş & 2,86 & 0,84 & & & \\
\hline & 45 yaş ve üzeri & 2,48 & 0,82 & & & \\
\hline \multirow{4}{*}{ Kişisel Başarı Eksikliği } & 25 yaş ve altı & 3,25 & 0,37 & 3,132 & $0,025^{*}$ & $2-4$ \\
\hline & $26-34$ yaş & 3,29 & 0,71 & & & \\
\hline & $35-44$ yaş & 3,40 & 0,65 & & & \\
\hline & 45 yaş ve üzeri & 3,58 & 0,82 & & & \\
\hline \multirow{4}{*}{ Duyarsızlaşma } & 25 yaş ve altı & 2,45 & 0,78 & 1,842 & 0,139 & - \\
\hline & $26-34$ yaş & 2,28 & 0,86 & & & \\
\hline & $35-44$ yaş & 2,12 & 0,84 & & & \\
\hline & 45 yaş ve üzeri & 2,09 & 0,93 & & & \\
\hline
\end{tabular}


Tablo 5'te yer alan tek yönlü varyans analizi sonuçlarına göre duygusal tükenme $(\mathrm{P}=0,010 ; \mathrm{P}<0,05)$ ve kişisel başarı eksikliği $(\mathrm{P}=0,025 ; \mathrm{P}<0,05)$ alt boyutlarında anlamlı farklılıklar tespit edilmiştir. Ancak duyarsızlaşma alt boyutunda ise $(\mathrm{P}=0,139 ; \mathrm{P}>0,05)$ anlamlı bir farklılık bulunamamıstır.

Tablo 6. Tükenmişlik Ölçeğindeki Boyutlarn Eğitim Düzeyine Göre Karşıllașturlması

\begin{tabular}{|c|c|c|c|c|c|c|}
\hline $\begin{array}{c}\text { Tükenmişlik Ölçeğindeki } \\
\text { Boyutları }\end{array}$ & $\begin{array}{l}\text { Eğgitim } \\
\text { Düzeyi }\end{array}$ & $\overline{\mathrm{X}}$ & S.S. & $\mathbf{F}$ & $\mathbf{P}$ & Tukey \\
\hline Duygusal Tükenme & $\begin{array}{l}\text { Lise } \\
\text { Ön Lisans } \\
\text { Lisans } \\
\text { Lisansüstü }\end{array}$ & $\begin{array}{l}2,62 \\
2,62 \\
2,82 \\
2,85\end{array}$ & $\begin{array}{l}0,92 \\
0,85 \\
0,82 \\
0,85\end{array}$ & 1,886 & 0,131 & - \\
\hline Kişisel Başarı Eksikliği & $\begin{array}{l}\text { Lise } \\
\text { Ön Lisans } \\
\text { Lisans } \\
\text { Lisansüstü }\end{array}$ & $\begin{array}{l}3,58 \\
3,52 \\
3,29 \\
3,64 \\
\end{array}$ & $\begin{array}{l}0,66 \\
0,71 \\
0,70 \\
0,36\end{array}$ & 4,947 & $0,002^{*}$ & $\begin{array}{l}1-3 \\
2-3\end{array}$ \\
\hline Duyarsızlaşma & $\begin{array}{l}\text { Lise } \\
\text { Ön Lisans } \\
\text { Lisans } \\
\text { Lisansüstü }\end{array}$ & $\begin{array}{l}2,22 \\
2,14 \\
2,18 \\
2,41\end{array}$ & $\begin{array}{l}0,96 \\
0,98 \\
0,83 \\
0,95\end{array}$ & 0,467 & 0,705 & - \\
\hline
\end{tabular}

Eğitim düzeyine göre tek yönlü varyans analizi sonuçları Tablo 6'da yer almaktadır. Bu bulgulara göre, duygusal tükenme $(\mathrm{P}=0,131 ; \mathrm{P}>0,05)$ ve duyarsızlaşma $(\mathrm{P}=0,705 ; \mathrm{P}>0,05)$ alt boyutlarında anlamlı bir farklılık bulunamamıştır. Ancak kişisel başarı eksikliği $(\mathrm{P}=0,002 ; \mathrm{P}<0,05)$ alt boyutunda anlamlı bir farklılık tespit edilmiştir.

Tablo 7. Tükenmişlik Ölçeğindeki Boyutlarn Medeni Duruma Göre Karşılaştırlması

\begin{tabular}{|c|c|c|c|c|c|}
\hline Tükenmişlik Ölçeğindeki Boyutları & $\begin{array}{l}\text { Medeni } \\
\text { Durum }\end{array}$ & $\overline{\mathrm{X}}$ & S.S. & $\mathrm{t}$ & $\mathbf{P}$ \\
\hline \multirow{2}{*}{ Duygusal Tükenme } & Evli & 2,74 & 0,89 & $-0,634$ & 0,526 \\
\hline & Bekâr & 2,80 & 0,83 & & \\
\hline \multirow{2}{*}{ Kişisel Başar1 Eksikliği } & Evli & 3,40 & 0,71 & 0,720 & 0,472 \\
\hline & Bekâr & 3,34 & 0,68 & & \\
\hline \multirow{2}{*}{ Duyarsızlaşma } & Evli & 2,14 & 0,86 & $-1,992$ & $0,047^{*}$ \\
\hline & Bekâr & 2,34 & 0,86 & & \\
\hline
\end{tabular}

Tükenmişlik ölçeğindeki alt boyutların medeni duruma göre karşılaştırılmasına yönelik bağımsız örneklemler için t testi sonuçları Tablo 7'de yer almaktadır. Buna göre, duyarsızlaşma $(\mathrm{P}=0,047 ; \mathrm{P}<0,05)$ alt boyutu için anlamlı bir farklılık gözlemlenirken duygusal tükenme $(\mathrm{P}=0,526 ; \mathrm{P}>0,05)$ alt boyutu ile kişisel başarı eksikliği $(\mathrm{P}=0,472 ; \mathrm{P}>0,05)$ alt boyutunda medeni duruma göre anlamlı bir farklılık tespit edilememiştir.

Tablo 8. Tükenmişlike Ölçeğindeki Boyutlar Çocuk Sayısına Göre Karşılaştırılması

\begin{tabular}{|c|c|c|c|c|c|c|}
\hline $\begin{array}{c}\text { Tükenmişlik Ölçeğindeki } \\
\text { Boyutları }\end{array}$ & Çocuk Sayısı & $\overline{\mathrm{X}}$ & S.S. & $\mathbf{F}$ & $\mathbf{P}$ & Tukey \\
\hline \multirow{4}{*}{ Duygusal Tükenme } & Yok & 2,83 & 0,82 & 0,639 & 0,590 & - \\
\hline & 1 & 2,73 & 0,85 & & & \\
\hline & 2 & 2,76 & 0,85 & & & \\
\hline & 3 ve daha fazla & 2,63 & 0,85 & & & \\
\hline \multirow{4}{*}{ Kişisel Başar1 Eksikliği } & Yok & 3,31 & 0,66 & 1,486 & 0,218 & - \\
\hline & 1 & 3,36 & 0,65 & & & \\
\hline & 2 & 3,40 & 0,73 & & & \\
\hline & 3 ve daha fazla & 3,57 & 0,74 & & & \\
\hline \multirow{4}{*}{ Duyarsızlaşma } & Yok & 2,36 & 0,88 & 1,964 & 0,119 & - \\
\hline & 1 & 2,12 & 0,79 & & & \\
\hline & 2 & 2,14 & 0,88 & & & \\
\hline & 3 ve daha fazla & 2,13 & 0,87 & & & \\
\hline
\end{tabular}

Tablo 8'de yer alan tükenmişlik ölçeğindeki alt boyutların çocuk sayılarına göre karşılaştırılmasında anlamlı bir farklılık bulunamamıstır. 
ÇEVİK ve ÖZBALCI

Sağlık Çalışanlarının Tükenmişlik Düzeyleri ile Demografik Özellikleri Arasındaki İlişki -Samsun İli Örneği-

Tablo 9. Tükenmislike Ölçeğindeki Boyutların Istibdam Şekline Göre Karşılaştırlması

\begin{tabular}{|c|c|c|c|c|c|}
\hline Tükenmişlik Ölçeğindeki Boyutları & $\begin{array}{c}\text { İstihdam } \\
\text { Şekli }\end{array}$ & $\overline{\mathrm{X}}$ & S.S. & $\mathbf{t}$ & $\mathbf{P}$ \\
\hline \multirow{2}{*}{ Duygusal Tükenme } & Memur & 2,76 & 0,83 & \multirow[t]{2}{*}{0,196} & \multirow[t]{2}{*}{0,844} \\
\hline & Sözleşmeli & 2,74 & 0,87 & & \\
\hline \multirow{2}{*}{ Kişisel Başarı Eksikliği } & Memur & 3,38 & 0,73 & \multirow[t]{2}{*}{$-0,519$} & \multirow[t]{2}{*}{0,604} \\
\hline & Sözleşmeli & 3,42 & 0,61 & & \\
\hline \multirow{2}{*}{ Duyarsızlaşma } & Memur & 2,17 & 0,83 & \multirow[t]{2}{*}{$-0,896$} & \multirow[t]{2}{*}{0,371} \\
\hline & Sözleșmeli & 2,25 & 0,96 & & \\
\hline
\end{tabular}

Tükenmişlik ölçeğindeki alt boyutların istihdam şekline göre karşıllaştırılmasında Tablo 9'da yer alan t testi sonuçlarına göre anlamlı bir farklılık tespit edilememiştir.

Tablo 10. Tükenmislike Ölçeğindeki Boyutlarn Meslekteki Toplam Görev Süresine Göre Karşılaştırlması

\begin{tabular}{|c|c|c|c|c|c|c|}
\hline $\begin{array}{l}\text { Tükenmişlik Ölçeğindeki } \\
\text { Boyutları }\end{array}$ & $\begin{array}{c}\text { Meslekteki } \\
\text { Toplam Görev } \\
\text { Süresi } \\
\end{array}$ & $\overline{\mathrm{x}}$ & S.S. & $\mathbf{F}$ & $\mathbf{P}$ & Tukey \\
\hline \multirow[t]{6}{*}{ Duygusal Tükenme } & 1 Yildan Az & 2,32 & 0,81 & 1,551 & 0,173 & - \\
\hline & 1-5 Yil & 2,86 & 0,65 & & & \\
\hline & 6-10 Yil & 2,78 & 0,81 & & & \\
\hline & $11-15 Y_{11}$ & 2,79 & 0,85 & & & \\
\hline & 16-20 Yil & 2,86 & 0,91 & & & \\
\hline & 20 Yildan Fazla & 2,60 & 0,88 & & & \\
\hline \multirow{6}{*}{ Kişisel Başarı Eksikliği } & 1 Yildan Az & 3,59 & 0,65 & 5,771 & $0,000^{* *}$ & $2-6$ \\
\hline & 1-5 Yil & 3,13 & 0,60 & & & $3-6$ \\
\hline & 6-10 Yil & 3,32 & 0,69 & & & $4-6$ \\
\hline & 11-15 Y1l & 3,31 & 0,68 & & & $5-6$ \\
\hline & 16-20 Yll & 3,34 & 0,71 & & & \\
\hline & 20 Yildan Fazla & 3,73 & 0,69 & & & \\
\hline \multirow{6}{*}{ Duyarsızlaşma } & 1 Yildan Az & 2,23 & 0,87 & 2,327 & $0,042^{*}$ & $2-6$ \\
\hline & 1-5 Yil & 2,40 & 0,78 & & & \\
\hline & $6-10 Y_{11}$ & 2,23 & 0,87 & & & \\
\hline & 11-15 Yil & 2,22 & 0,89 & & & \\
\hline & 16-20 Yil & 2,25 & 0,75 & & & \\
\hline & 20 Yildan Fazla & 1,91 & 0,89 & & & \\
\hline
\end{tabular}

Tükenmişlik ölçeğindeki alt boyutların meslekteki toplam görev süresine göre karşılaştırılmasına yönelik tek yönlü varyans analizi sonuçları Tablo 10'da sunulmuştur. Bu bulgulara göre, kişsisel başarı eksikliği $(\mathrm{P}=0,000 ; \mathrm{P}<0,05)$ ve duyarsızlaşma $(\mathrm{P}=0,042 ; \mathrm{P}<0,05)$ alt boyutları için anlamlı bir farklılık görülürken, duygusal tükenme $(\mathrm{P}=0,173 ; \mathrm{P}>0,05)$ alt boyutu için anlamlı bir farklılık tespit edilememiştir.

Tablo 11. Tükenmişlike Ölçeğindeki Boyutlarn Kurumdaki Görev Süresine Göre Karşılaştırlması

\begin{tabular}{|c|c|c|c|c|c|c|}
\hline $\begin{array}{c}\text { Tükenmişlik Ölçeğindeki } \\
\text { Boyutları }\end{array}$ & $\begin{array}{l}\text { Kurumdaki } \\
\text { Görev Süresi }\end{array}$ & $\overline{\mathrm{X}}$ & S.S. & $\mathbf{F}$ & $\mathbf{P}$ & Tukey \\
\hline \multirow{6}{*}{ Duygusal Tükenme } & 1 Ylldan Az & 2,74 & 0,84 & \multirow[t]{6}{*}{1,095} & \multirow[t]{6}{*}{0,363} & \multirow[t]{6}{*}{-} \\
\hline & 1-5 Y1l & 2,73 & 0,84 & & & \\
\hline & 6-10 Y1l & 2,76 & 0,82 & & & \\
\hline & 11-15 Y1l & 2,87 & 0,87 & & & \\
\hline & $16-20 \mathrm{Y}_{11}$ & 2,84 & 0,90 & & & \\
\hline & 20 Yildan Fazla & 2,50 & 0,80 & & & \\
\hline \multirow{6}{*}{ Kişisel Başarı Eksikliği } & 1 Yldan Az & 3,36 & 0,59 & \multirow[t]{6}{*}{4,176} & \multirow[t]{6}{*}{$0,001^{*}$} & $1-6$ \\
\hline & $1-5 Y_{1}$ & 3,31 & 0,72 & & & $2-6$ \\
\hline & 6-10 Yil & 3,32 & 0,75 & & & $3-6$ \\
\hline & 11-15 Y1l & 3,36 & 0,69 & & & $4-6$ \\
\hline & $16-20 Y_{11}$ & 3,45 & 0,56 & & & \\
\hline & 20 Yildan Fazla & 3,86 & 0,63 & & & \\
\hline \multirow{6}{*}{ Duyarsızlaşma } & 1 Yildan Az & 2,23 & 0,83 & \multirow[t]{6}{*}{1,251} & \multirow[t]{6}{*}{0,284} & \multirow[t]{6}{*}{-} \\
\hline & $1-5 Y_{1}$ & 2,29 & 0,85 & & & \\
\hline & 6-10 Y1l & 2,15 & 0,86 & & & \\
\hline & 11-15 Y1l & 2,19 & 0,89 & & & \\
\hline & $16-20 \mathrm{Y}_{11}$ & 2,29 & 0,81 & & & \\
\hline & 20 Yildan Fazla & 1,91 & 0,92 & & & \\
\hline
\end{tabular}


Tükenmişlik ölçeğindeki alt boyutların kurumdaki görev sürelerine göre karşısştırılmasına yönelik tek yönlü varyans analizi sonuçları Tablo 11 'de sunulmuştur. Bu bulgulara göre, kişisel başarı $(\mathrm{P}=0,001$; $\mathrm{P}<0,05)$ alt boyutu için anlamlı bir farkll1k görülürken duygusal tükenme $(\mathrm{P}=0,363 ; \mathrm{P}>0,05)$ ve duyarsızlaşma $(\mathrm{P}=0,284 ; \mathrm{P}>0,05)$ alt boyutları için anlamlı bir farklılık tespit edilememiştir.

Tablo 12. Tükenmişlik Ölçeğindeki Boyutlarn Kurumdaki Požsyonuna Göre Karşılaştırlması

\begin{tabular}{|c|c|c|c|c|c|c|}
\hline $\begin{array}{l}\text { Tükenmişlik } \\
\text { Ölçeğindeki } \\
\text { Boyutları }\end{array}$ & Kurumdaki Pozisyon & $\overline{\mathrm{X}}$ & S.S. & $\mathbf{F}$ & $\mathbf{P}$ & Tukey \\
\hline \multirow{3}{*}{ Duygusal Tükenme } & Ebe-Hemşire & 2,97 & 0,83 & 16,265 & $0,000^{*}$ & $1-2,3$ \\
\hline & Sağlık Hizmetleri Sınıfi & 2,46 & 0,78 & & & $2-1$ \\
\hline & Genel İdari Hizmetler Sinıfi & 2,66 & 0,81 & & & $3-1$ \\
\hline \multirow{3}{*}{ Kişisel Başarı Eksikliği } & Ebe-Hemşire & 3,42 & 0,66 & 0,551 & 0,577 & - \\
\hline & Sağlık Hizmetleri Sınıfı & 3,35 & 0,71 & & & \\
\hline & Genel İdari Hizmetler Sinıfi & 3,36 & 0,76 & & & \\
\hline \multirow{3}{*}{ Duyarsızlaşma } & Ebe-Hemşire & 2,22 & 0,83 & 2,672 & 0,070 & - \\
\hline & Sağl1k Hizmetleri Sınıfı & 2,03 & 0,86 & & & \\
\hline & Genel İdari Hizmetler Sınıfi & 2,27 & 0,90 & & & \\
\hline
\end{tabular}

Tükenmişlik ölçeğindeki alt boyutlanın kurumdaki pozisyonuna göre karşılaştırılmasına yönelik tek yönlü varyans analizi sonuçları Tablo 12'de sunulmuştur. Buna göre, duygusal tükenme $(\mathrm{P}=0,000 ; \mathrm{P}<0,05)$ alt boyutu için anlamlı bir farklılık görülürken kişisel başarı eksiklĭgi $(\mathrm{P}=0,577 ; \mathrm{P}>0,05)$ ve duyarsızlaşma $(\mathrm{P}=0,284 ; \mathrm{P}>0,05)$ alt boyutları için anlamlı bir farklılık tespit edilememiştir.

\section{Tartışma}

Dünya Sağlık Örgütü ve Avrupa Tip Dernekleri tarafindan Şubat 2003’te Berlin'de, gerçekleştirilen forumda tıp meslek çalışanları arasında tükenmişliğin giderek arttığı ve bu durumun sadece hekimleri değil sunulan sağlık hizmetinin kalitesini ve hasta bakımını da etkileyen bir durum olduğu bildirilmiştir (WHO, 2002). Düzenlenen forumdan hareketle bu çalşmada, Samsun ilinde bulunan beș kamu hastanesinde görev yapan sağlık çalışanlarının tükenmişlik (duygusal tükenme, duyarsızlaşma, kişisel başarı) düzeyleri ve tanımlayıcı özellikleri değerlendirilmeye çalıssılmışıı. Bu amaçla çalışanların tükenmişlik düzeyleri "Maslach tükenmişlik ölçeği” ile ölçülmüştür. Araştırma sonucunda sağlı çalışanlarının tükenmişlik düzeyleri ortalamaları, duygusal tükenme için 2,76; kişisel başarı eksikliği için 3,39 ve duyarsızlaşma için 2,19 olarak bulunmuştur. Araştırmada duygusal tükenme, kişisel başarı eksikliği ve duyarsızlaşma arasında anlamlı ilişki bulunmuştur. Aritmetik ortalama değerlerine göre araştırmanın örneklem grubundaki sağlık çalışanlarının diğer boyutlara göre en çok kişisel başarı eksikliği $(\bar{x}=3,39)$ boyutunu benimserken orta düzeyde duygusal tükenme $(\bar{x}=2,76)$ boyutunu ve en az düzeyde duyarsızlaşma $(\bar{x}=2,19)$ boyutunu benimsedikleri görülmüştür.

Araştırmanın öncelikli amacı olan sağlık çalışanlarının tükenmişlik düzeylerinin belirlenmesi noktasında tükenmişlik "vardır" veya "yoktur" gibi ifadelerin yerine; yüksek, orta ve düşük tükenmişlik düzeyi şeklinde ifadelerin kullanılması gerekmektedir. İfadelere ait puanlamada 5 'in en yüksek düzeyi ifade ettiği değerlendirildiğinde, araştırma kapsamındaki sağlık çalışanlarının tükenmişlik düzeylerinin orta seviyede olduğu görülmektedir. Başka bir ifade ile örneklem içerisindeki sağlık çalışanları orta seviyede bir tükenmişlik düzeyine sahiptir. Sağllk kurumlarının ve burada görevli olan personelin toplum için ne kadar önemli bir hizmeti yerine getirdiği düşünüldüğ̈̈nde ortaya çıkan sonucun sağllk hizmeti sunumu kalitesi açısından üzücü bir durumda olduğu ifade edilebilir.

Araştırmanın diğer bir amacı; sağlık çalışanlarının tükenmişlik düzeylerinin cinsiyet, yaş, eğitim durumu, medeni durum, çocuk sayısı, istihdam şekli, meslekte toplam çalışma süresi, kurumdaki toplam çalışma süresi ve sağlık kurumundaki pozisyonu gibi değişkenlere göre farklılaşıp farklılaşmadığını belirlemektir. Bu alanda yapılan çalışmalar tükenmişliğin kişisel, toplumsal ve mesleki açıdan birçok faktörden etkilendiği, bireysel özelliklerden kaynaklı etkenlerin tükenmişliği etkileyen faktörler olduğunu ortaya koymaktadır (Öztürk, Çetin, Yıldıran, Türk ve Fedai, 2012; Yavuzyılmaz, Topbaş, Çan ve Özgün, 2007).

Araştırma bulgularına bakıldığında, cinsiyet değişkeninin tükenmişliğe anlamlı bir etkisi olmadığ1 görülmektedir. Ergin (1993), cinsiyetin önemli bir tükenmişlik değişkeni olduğunu; duyarsızlaşma alt boyutunun iki cinsiyette farklı olmasa da kadınlarda duygusal tükenmenin daha fazla olduğunu, erkeklerin 
ise kişisel başarı eksikliği duygusunda azalmayı daha fazla yaşadığını bildirmektedir (Ergin, 1993). Schweitzer'in (1994) genç hekimler üzerinde yapmış olduğu bir çalışmada ise cinsiyetler arasında fark gözlenmemiştir. Bu konudaki genel görüş, kadınların cinsiyet rolleri gereği karşılarındaki insanları daha fazla gözetmeleri ve önem vermelerinin, duygusal tükenmelerini artırdığı biçimindedir (Schweitzer, 1994). Yaman ve Urgan (2002), aile hekimliği asistan hekimlerinin tükenmişlik algılamaları üzerine yaptıkları araştırmada üç tükenmişlik boyutu açısından cinsiyete göre anlamlı farklılık bulamamıştır (Yaman ve Urgan, 2002). Aritmetik ortalamalardaki farklılıklara göre, duygusal tükenme kadınlarda erkeklerden daha fazla olurken kişisel başarı eksikliği ve duyarsızlaşmanın erkeklerde daha fazla olduğu görülmektedir. Cinsiyet değişkeninin tükenmişlik üzerinde farklılık oluşturup oluşturmadığı tartışmalı bir konudur. Literatürde bu değişkenin tükenmişliği etkilediğine dair bulgular olmakla birlikte, bunun karşıtı bulgularda yer almaktadır. Maslach, Jackson (1985) ve Greenglass, Burke'un (1987) yapmış oldukları araştırmalar sonucunda tükenmişlik düzeyi için cinsiyet değişkeninin ciddi derecede önemli bir yordayıc1 olmadı̆̆1 belirtilmiştir. Erkek ve kadın çalışanlar arasındaki farkın çok az olması nedeniyle önemli yorumların yapılmaması gerektiği vurgulanmaktadır (Sayıl vd. 1997, s. 75; Pelit ve Türkmen, 2008, s. 131). Bu çalısmada tükenmişlik düzeyleri bakımından cinsiyet değişkeninin çok az bir etkisi olması araştırma kapsamındaki kurum içi faktörlerin kadın ve erkek sağlık çalışanlarını eşit ölçüde etkilediğinin göstergesi olabilir.

Yaş değişkenine göre ortaya çıkan sonuçlar değerlendirildiğinde, duygusal tükenme ve kişisel başarı eksikliği için anlamlı bir farklılık olduğu görülmektedir. Duygusal tükenmenin genç yaştaki çalışanlarda daha yüksek ve kişisel başarı eksikliğinin ise ileri yaştaki çalışanlarda daha yoğun bir şekilde hissedildiği saptanmaktadır. Bunun nedeni olarak ileri yaştaki çalışanların tecrübelerinin de etkisi ile genç yaştaki çalışanlara nazaran daha deneyimli, olgun ve sabırlı olmaları nedeni ile tükenme duygusuna karşı bir direnç oluşturmalarıdır. Buna ek olarak ileri yaşlarda kazanılan önemli görev ve sorumlulukların tükenme duygusunu azalttı̆̆1 düşünülmektedir. Bu araştırmada ortaya çıkan bulguları destekleyen görüşler literatürde yer almaktadır (Maslach ve Jackson, 1981; Lee ve Ashford, 1993; Ergin, 1995; Izgar, 2001).

Goldberg ve arkadaşlanı (1996) tarafindan yapılan araştırmada, yaş ve çalışma yılı sayısının tükenmişliğin önemli bir belirleyicisi olmadığı tespit edilmiş̧tir. Türk Tabipler Birliği tarafindan yapılan bir çalışmada 35-44 yaş grubu hekimlerde duygusal tükenme puanı daha fazla bulunmuş ve 25-34 yaş grubunda duyarsızlaşma puanının en yüksek olduğu, yaş arttıkça duyarsızlaşma puanının azaldığı görülmüsstür (Aslan vd. 2005). Öztürk'ün çalışmasinda da genç ve görev süresi kısa olan hekimlerin tükenmişlik puanlarının daha yüksek olduğu gösterilmiştir (Öztürk, Çetin, Yıldıran, Türk ve Fedai, 2012). Başka bir çalışmasında ise yaş arttıkça duyarsızlaşma ve duygusal tükenme puanlarının azaldığı belirlenmiştir. Tüm bu çalışmalar genç hekimlerin tükenmeye daha yatkın olduğunu göstermektedir. Bu çalışmada da yaşla birlikte duygusal ve toplam tükenmişlik puanlarının azaldığı gösterilmiştir (Buğdaycı vd. 2004, s. 307).

Araştırmadan elde edilen bulgular neticesinde eğitim düzeyi değişkeni için kişisel başarı eksikliği açısından anlamlı bir farklılık tespit edilirken duygusal tükenme ve duyarsızlaşma için bir farklılık bulunamamıştır. Kişisel başarı eksikliğinin en yoğun hissedildiği grup olarak lisansüstü mezuniyetine sahip sağlık çalışanlarının olduğu görülmektedir. Aritmetik ortalamalar üzerinden bir değerlendirme yapıldığında duygusal tükenmenin tüm eğitim düzeyleri için birbirine çok yakın puanlar ortaya çıkarması nedeni ile kesin bir yoruma ulaşılmamaktadır. Bunun yanında duyarsızlaşma hissi, yine lisansüstü mezunu olan sağlık çalışanlarında daha fazla gözlemlenmiştir. Eğitim düzeyinin tükenmişliğin alt boyutlanna etkisi ile ilgili literatürde çelişkili sonuçlara ulaşıldığ görülmektedir. Çalışmaların bir bölümünde tükenmişlik ile eğitim düzeyi arasında ters bir ilişki olduğu sonucuna varılırken diğer bir bölümünde ise eğitim düzeyi arttıkça tükenmişliğinde arttı̆̆ sonucuna ulaşılmıştır (Çimen ve Ergin, 2001; Maslach vd. 2001). Bu çalışmada eğitim düzeyi yüksek olan sağlık çalışanlarında kişisel başarı eksikliği hissinin daha fazla olduğu görülmektedir.

Sağlık çalışanlarının medeni durumunun tükenmişliği etkileyen faktörler arasında yer aldığını belirten çalısmalar bulunmaktadır (Maslach ve Jackson, 1981, s. 111; Cordes ve Dougherty, 1993, s. 632). Medeni duruma ilişkin yapılan karşılaştırmada duyarsızlaşma için anlamlı bir farklılık gözlemlenirken duygusal tükenme ve kişisel başarı eksikliği açısından anlamlı bir farklılık tespit edilememiştir. Bekâr olanların evli olanlara göre duyarsızlaşma hissini yoğun olarak yaşadığı görülmektedir. Duyarsızlaşma alt boyutu için aritmetik ortalamalar incelendiğinde; sorumluluk alanları evli olan çalışanlara kıyasla daha dar olan bekâr çalışanların duyarsızlaşma düşüncesinin daha yüksek olduğu söylenebilir. Bulguların aritmetik ortalamaları açısından duygusal tükenme ve duyarsızlığı ele alındığında bekâr olanların evlilere oranla duygusal tükenme 
yaşadığı, evlilerin ise bekârlardan daha çok kişisel başarı eksikliği hissettiği görülmektedir. Evli olan sağlık çalışanlarının bekârlara göre daha fazla sorumluluk sahibi olmaları, işlerine ve kuruma olan bağllılkları açısından aidiyet duygusunun daha fazla gelişmiş olduğu düşünülebilir. Ayrıca evli bir insanın kişisel başarı eksikliği düşüncesi ve bu yönde emek harcaması sorumluluklarının gereği ile olduğu düşünüldüğünde evli olan çalşsanların duygusal tükenme ve duyarsızlaşma gibi düşüncelere karşı bir direnç geliştirdiği varsayılabilir. Bazı çalışmalarda tükenmişliğe etkisi bakımında medeni durumun özellikle duygusal tükenme alt boyutu üzerinde etki ettiğine dair sonuçlara ulaşılmıştır (Ramires vd. 1996).

Araştırma kapsamında çocuk sayılarına ait anlamlı bir farklılık bulunamamıştır. Ancak bekâr olan sağlık çalışanlarında olduğu gibi çocuğu olmayanlarda duyarsızlaşmanın daha fazla olduğu, kişisel başarı eksikliğinin ise birden fazla çocuğu olan çalışanlarda arttığı görülmektedir. Özetle medeni durum ve çocuk sayısının benzer yönde etki ettiği söylenebilir. Ortaya çıkan bulgular, literatürdeki diğer araştırmalarla benzerlik göstermektedir (Maslach vd. 1981; Lee ve Ashford, 1993).

Çiper'e (2006) göre; Bekârların evlilere ve çocuk sahibi olmayanların çocuk sahibi olanlara oranla daha yoğun düzeyde tükenmişlik hissi yaşadıkları görülmektedir. Çalışmalar, duygusal tükenme hissini daha yoğun oranda yaşayanların hiç evlenmemiş, boşanmış ve evli fakat çocuksuz kişilerin olduğu görülmektedir. Tükenmişliğin etkilerinin daha az görüldüğü kişilerin özellikle aile sahibi olan çalşanlar olduğunu ve bireyin ailesi tarafından sosyal bir desteğe sahip olabilmesinin önemli olduğu açıklanmaktadır.

Sağlık çalışanının hangi statü ile istihdam edildiği de tükenmişlik açısından önemli bir değişken olduğu ve tükenmişlik düzeylerini etkilediği çeşitli araştırmalarda tespit edilmiştir. Akbolat ve diğerleri (2008) tarafından yapılan çalışmada memur statüsünde görevlendirilen sağlık çalışanlarının tükenmişlik düzeylerinin sözleşmeli çalışanlara oranla daha yüksek olduğu tespit edilmiştir. Memur kadrosundaki çalışanların günlerinin iyi geçmediğini ve başlarının dertte olduğunu düşündükleri ve geleceğe dair umutlu olmadıkları belirtilmiştir. Ancak bu araştırmanın bulgularına göre tükenmişlik ölçeğine ait alt boyutlar arasında anlamlı bir farklılık tespit edilememiştir. Bunun nedeni olarak sağlık alanında sözleşmeli olarak çalışan personel ile memur olarak çalışan personelin 24.12.2017tarihli KHK696 (KHK696, 2017) ile aynı özlük hakları kazanmasının etkisi olabileceği düşünülmektedir.

Çeşitli araştırmalarda meslekteki toplam çalş̧̧ma süresi ve kurumdaki toplam çalışma süresi ile tükenmişlik arasında pozitif yönlü bir ilişki olduğu çeşitli çalışmalarda gösterilmiş̧ir (Tuğrul ve Çelik, 2002; Kırılmaz, Çelen ve Sarp, 2003; Cemaloğlu ve Erdemoğlu, 2007). Bireysel özellik bakımından bu çalışmada, kişisel başarı eksikliği ve duyarsızlaşmanın anlamlı bir farklılık oluşturduğu fakat duygusal tükenme açısından bir farklılık olmadığı görülmektedir. Her iki değişken için kişisel başarı eksikliğinin önemli bir etki yarattığı görülürken en az ve en çok çalışma süresine sahip çalışanlarda daha yoğun görülmektedir. Daha açık bir ifade ile tecrübeli ve tecrübesiz olanların kişisel başarı eksikliğini daha fazla yaşadığı görülmektedir. Diğer yandan meslek hayatının sonunda olanlarda ise duyarsızlaşma hissinin en az olduğu görülmektedir. Akbolat ve Işık (2008) tarafindan yapılan araştırmada yirmi yıldan fazla süre çalışan bireylerin geleceğe dair umutlarını kaybettikleri ve kendilerini kapana kısılmış gibi hissettikleri ifade edilmiştir. Buna ek olarak, bir diğer çalışsmada meslekte çalışma süresi ile duyarsızlaşma puanları arasında istatistiksel olarak anlamlı ve azalan bir ilişki bulunmuştur (Kayavd. 2007).

Sağlık kurumlarında çalışanlar kurumdaki pozisyon ve sorumluklarına göre gruplandırıldığında sadece duygusal tükenme alt boyutu için anlamlı bir farklılık görülmektedir. Duygusal tükenmenin daha çok ebe ve hemşireler tarafindan yaşandığı görülmektedir. Ebe ve hemşirelerin sürekli olarak hastalarla iletişim hâlinde olduğu, hata yapma şanslarının diğer katıllımcılara oranla daha az olduğu düşünüldüğünde ebehemşire grubunda görev yapan sağlık çalışanlarının duygusal tükenme düşüncesine sahip olmasının görev tanımlarındaki sorumluluk ve yüksek risk faktörünün fazla olmasından kaynaklandığ1 söylenebilir. Tükenmişlik düzeyine unvanların genel bir etkisinin olmadığını ancak hemşirelerin daha mutsuz olduğu, kendilerini fiziksel olarak daha güçsüz ve bitkin hissettiklerini tespit eden çalışmalar bulunmaktadır (Akbolat ve Işık, 2008, s. 250). Bu sonuçtan hareketle hemşirelerin tükenmişlik düzeylerinin diğer grup çalışanlara göre daha yüksek olduğu düşünülmektedir.

\section{Sonuç ve Öneriler}

Sağlık çalışanları, görevlerinin gereği olarak hem çalısma arkadaşları hem de hizmet sundukları hastalar ile yoğun iletişim kurmak zorunda oldukları yüksek tempolu bir iş ortamında çalışmaktadırlar. $\mathrm{Bu}$ ortam içerisinde kendilerini rahat, huzurlu ve mutlu hissetmeleri, üstlendikleri ağır sorumluluğun gereği 
olarak kişisel başarı hissi açısından tatmin olmaları gerekmektedir. Sağlık çalışanlarından özverili ve kaliteli bir sağlık hizmeti sunumu beklemek için, duygusal açıdan konforlu, kişisel başarı seviyesi yüksek ve sorumlu olduğu görev ve bireylere karşı duyarlı bireylerden oluşan bir çalışma ortamı gereklidir. Bundan dolayıdır ki sağlık çalışanlarının mesleki tükenmişlik düzeyinin belli periyotlarda araştırılması hem bireysel hem de örgütsel olarak önemli bir inceleme alanı hâline gelmiştir.

Samsun ili sınırları içinde sağlık hizmeti sunmakta olan kamu hastanelerinde görevli sağlık çalışanlarında bireysel değişkenlerin tükenmişlik düzeyine olan etkisi değerlendirildiğinde çalışanlar arasında tükenmişlik sendromunun bulunduğu ve orta seviyede olduğu görülmektedir. En temel noktada, tükenmişlik düzeyinin asgari seviyeye düşürülmesi için çalsşanların bir değer olarak görüldüğ̈̈ hissinin oluşmasında gerekli adımların atılması, kurum ve toplum için değer olarak kabul edildikleri ve sağlık hizmetinin verilmesinde her çalışanın ekibin bir parçası olduğuna dair inancının tam olması gerekmektedir.

Çalışmadan elde edilen sonuçlara göre, sözü edilen sağlık çalışanlarında cinsiyet, çocuk sayısı ve istihdam şeklinin tükenmişlik düzeylerini etkilemeyen bireysel değişkenler olduğu görülmüştür. Bunun yanında yaş, eğitim düzeyi, medeni durum, meslekteki toplam çalışma süresi, kurumdaki toplam görev süresi ve kurumdaki pozisyonun ise etkileyen değişkenler olduğu tespit edilmiştir.

Tükenmişliği ve alt boyutlarını etkileyen değişkenlere ait sonuçlara bakıldı̆̆ında;

1. Duygusal tükenmişlik hissinin 25 yaş ve altı bireylerde yoğun olarak hissedildiği ancak 45 yaş ve üzerinde olan bireylerde ise en alt seviyede olduğu, kişisel başarı eksikliği hissi için durumun duygusal tükenmenin tam tersi olduğu,

2. Eğitim düzeyinin etkilediği kişisel başarı hissinin en yoğun hissedildiği lisansüstü mezunu olan çalışanlarken bu durumun en az hissedildiği grubun lisans mezunu olan çalışanlarda olduğu,

3. Tükenme hissini medeni durumun etkilediği ve bekâr çalışanların evli olanlara kıyasla daha fazla duyarsızlaştı̆̆

4. Meslekteki toplam görev süresinin kişisel başarı eksikliği hissini etkilediği, bu hissin 20 yıldan fazla çalışanlarda daha yoğun, 1-5 yıl arasında mesleğe yeni başladı̆̆ı kabul edilen grupta ise en az hissedildiği ve bunun yanında duyarsızlaşma hissinin tam tersi yönde hissedildiği,

5. 20 yıldan daha fazla süredir aynı kurumda çalışanların kişisel başarı eksikliği hissini en az yaşadığı, kurumda 16-20 yıl arası çalışan kişilerin ise daha yoğun hissettiği,

6. Kurumdaki pozisyonu bakımından duygusal tükenme hissini en yoğun şekilde yaşayanların ebehemşire sınıfına dâhil olan çalışanlar olduğu görülmektedir.

$\mathrm{Bu}$ sonuçlardan hareketle tükenmişlik düzeyinin asgari seviyeye düşürülmesi için şu öneriler ileri sürülebilir;

1. Tükenmişlik düzeyi yüksek olan ebe-hemşire grubunda görev yapan çalışanların çalışma ortamları ve iş yükünün uygun şekilde düzenlenmesi, iş kaynaklı nedenlerle meydana gelen stresi azaltmak amaciyla tükenmişlik ile başa çıkma konusunda eğitim verilmesi,

2. Hastalarla sağlıklı iletişim ve doğru empati kurmaları için özellikle mesleğe yeni başlayan genç yaştaki çalışanların duyarlılı̆̆ını arttırmak adına uygun eğitimlerin verilmesi,

3. Çalışanlara görev ve sorumlukları ile ilgili olarak gerekli hizmet içi eğitimlerle sorumluluklarına uygun olarak çalışma düzeni, çalışanın görevin gerekliliklerini anlaması ve buna göre beklentilerini belirlemesi açısından yardımcı olacaktır.

4. Tükenmişlik sendromu sağlık çalışanını bireysel olarak etkilerken bulundukları kurumu ve hizmet sunma sorumluluklarını da etkilemektedir. Bu nedenle, çalışanların tükenmişlik düzeylerini belirlemek adına gerekli çalışmaların yapılarak gereken önlemlerin başta kurum olmak üzere sağlık çalışanları ile ortak olarak hayata geçirilmesi gerekmektedir. Bu gereklilik sağlık kurumlarında sunulan hizmetin kalitesini doğrudan etkilediği için çalışanların motivasyon kaynaklarını, beklentilerini, stres nedenlerini ve psikolojik durumlarını gözlemlemek önem arz etmektedir.

Bu çalışmada ortaya konulan sonuçlar, Türkiye'deki tüm sağlık çalışanlarını kapsamamaktadır. Sağlık hizmeti sunumunda faaliyet gösteren tüm kamu ve özel kuruluşlarda görev yapmakta olan çalışanların tükenmişlik düzeyleri ve tükenmişlik düzeylerini etkileyen diğer faktörler üzerine geniş kapsaml araştırmaların yapılması hem literatüre katkı sağlayacak hem de sağlık çalışanlarının insan kaynağı olarak daha verimli çalıştırılmasına yardımcı olacaktır. 


\section{Etik Beyan}

"Sağhlk Calışanlarmın Tükenmişlik Düzeyleri ile Demografike Özellikleri Arasındaki İlişki -Samsun İli Örneği-" başlıklı çalışmanın yazım sürecinde bilimsel, etik ve alıntı kurallarına uyulmuş; toplanan veriler üzerinde herhangi bir tahrifat yapılmamış ve bu çalışma herhangi başka bir akademik yayın ortamına değerlendirme için gönderilmemiştir.

\section{Kaynakça}

Akbolat, M. ve Iş1k, O. (2008). Sağlık çalışanlarının tükenmişlik düzeyleri: Bir kamu hastanesi örneği. Hacettepe Sağhlk İdaresi Dergisi, 11(2), 229-254.

Akbolat, M., Işık, O. ve Karadă̆, M. (2008). Tükenmişlik ve örgütten ayrılma ile ilgili tıbbi sekreterler üzerinde ampirik bir çalışma. 7. Ulusal Büro Yönetimi ve Sekereterlik. Kongresi (s. 393-406). Trabzon: Karadeniz Teknik Üniversitesi Beşikdüzü Meslek Yüksekokulu.

Aslan, D., Kiper, N., Karaağaoğlu, E., Topal, F., Güdük, M. ve Ös, C. (2005). Türkiye'de tabip odalarna kayntl olan bir grup hekimde tükenmişlik, sendromu ve etkileyen faktörler. Ankara: Türk Tabipler Birliği Yayınları.

Aşan, Ö. ve Aydın, M. (2006). Örgütsel davramıs (1. Baskı). Ankara: Arıkan Yayım.

Beemsterboer, J. ve Baum, J. (1984). Burnout: Definitions And Health Care. Social Work in Healthcare(10), 97-110.

Borkowski, N. (2005). Stress in the workplace and stress management. In N. Borkowski (Edt.). Organizational behavior in health care (pp. 231-269). Sudbury, Massachusetts: Jones and Bartlett Publishers.

Buğdayc1, R., Kurt, A., Şaşmaz, T. vd. (2004). Mersin ilinde görev yapan hekimlerde ruhsal tükenmişlik durumu ve etkileyen faktörler. 93 Ulusal Halk Sağhlğ Kongresi Bildiri Özet Kitabı (s. 307). Ankara: Hacettepe Üniversitesi.

Cemaloğlu, N. ve Erdemoğlu Şahin, D. (2007). öğretmenlerin mesleki tükenmişlik düzeylerinin farklı değişkenlere göre incelenmesi. Kastamonu Ë̆itim Dergisi, 15(2), 465-484.

Cordes, C. ve Dougherty, T. (1993). A review and an integration of research on job burnout. Academy of Management Review, 18(4), 621-656.

Çağllyan, Y. (2007). Tükenmislike sendromu ve iş doyumuna etkisi (devlet ve vakuf üniversitelerindeki akademisyenlere yönelik bir araştırma (Yayınlanmamış Yüksek Lisans Tezi). Kocaeli Üniversitesi, Sosyal Bilimler Enstitüsü, Kocaeli.

Çapri, B. (2006). Tükenmişlik ölçeğinin türkçe uyarlaması: geçerlilik ve güvenirlik çalışması. Mersin Üniversitesi, Eğitim Fakültesi Dergisi, 2(1), 62-77.

Çimen, M. ve Ergin, C. (2001). Türk silahlı kuvvetleri sağlık personelinin tükenmislik düzeylerinin incelenmesi. Gülhane T⿰力口 Dergisi, 43(2), 169-176.

Çiper, A. (2006). Tükenmişlik sendromu bizmet kalitesine etkisi ve çă̆r merkę̧i uygulaması (Yayınlanmamış Yüksek Lisans Tezi). Marmara Üniversitesi Sosyal Bilimler Enstitüsü, İstanbul.

Dikmetaş, E., Top, M. ve Ergin, G. (2011). Asistan hekimlerin tükenmişlik ve mobbing düzeylerinin incelenmesi. Türk Psikiyatri Dergisi, 22(3), 137-149.

Ergin, C. (1993). Doktor ve hemşirelerde tükenmişlik ve maslach tükenmişlik ölçeğinin uyarlanmasi. VII. Ulusal Psikoloji Kongresi Bilimsel Calışmalar (s. 143 - 160). Ankara: Türk Psikologlar Derneği Yayını.

Ergin, C. (1995). Akademisyenlerde tükenmişlik ve çeşitli stres kaynaklarının incelenmesi. Hacettepe Üniversitesi Edebiyat Fakültesi Dergisi, 12(1-2), 37-50.

Friberg, T. (2009). Burnout: From popular culture to psychiatric diagnosis in. Culture, Medicine and Psychiatry, 33(4), $538-558$.

Goldberg, R., Boss, R., Chan, L., Goldberg, J. vd. (1996). Burnout and its correlates in emergency physicians: four years' experience with a wellness booth. Academic Emergency Medicine, 3(12), 1156-1164.

Gürses, İ. (2006). Avukatlarn mesleki tükenmişlik düzeylerinin çeşitli deģ̆̈şlenler açısndan incelenmesi: sakarya örneği (Yayınlanmamış Yüksek Lisans Tezi). Sakarya Üniversitesi, Sosyal Bilimler Enstitüsü, Sakarya.

Hair, J., Anderson, R., Tatham, R. ve Black, W. (1998). Multivariate data analysis (2nd Edition). Englewood Cliffs: Prentice-Hall.

Izgar, H. (2001). Okul yöneticilerinde tükenmişlik. Ankara: Nobel Yayın Dağıtım.

Kaya, M., Üner, S., Karanfil, E., Uluyol, R., Yüksel, F. ve Yüksel, M. (2007). Birinci basamak sağlık çalışanlarının tükenmişlik durumları. TSK Koruyucu Hekimlik Bülteni, 6(5), 357-363.

KHK696. (2017, 12 24). Resmi Gazete. 10 18, 2019 tarihinde Resmi Gazete: https://www.resmigazete.gov.tr/eskiler/2017/12/20171224-22.htm adresinden alındı

Kırılmaz, A., Çelen, Ü. ve Sarp, N. (2003). İlköğretimde çalışan bir öğretmen grubunda tükenmişlik durumu araştırması. İlköğretim Online, 2(1), 2-9.

Kozak, M. (2001). Türkiye'de konaklama sektörü ve çalışan kadınların tükenmişlik durumları üzerine bir araştırma. Gazi Üniversitesi Turizm Akademik Dergisi, 2, 11-12.

Lee, R. ve Ashford, B. (1993). A further examination of managerial burnout: toward an integrated model. Journal of Organizational Behavior, 14, 3 -20.

Maslach, C. (2003). Job burnout: New directions in research and intervention. Current Directions in Psychological Science, 12(5), 189-192.

Maslach, C. ve Jackson, S. (1981). Maclach burnount inventory manual. Polo, Consulting Psychologist Press. 
Maslach, C., Jackson, S. ve Leiter, M. (1996). Maslach burnout inventory manual. Palo Alto, CA Consulting Psychologists Press.

Maslach, C., Schaufeli, W. ve Leiter, M. (2001). Job burnout. Annual Review of Psychology, 52, 397-422.

Özgüven, İ. (2003). Endistüri psikolojisi. Ankara: Nobel/Pdrem Yayınlar1.

Öztürk, A., Tolga, Y., Şenol, V. ve Günay, O. (2008). Kayseri ilinde görev yapan sağlık idarecilerinin tükenmişlik düzeylerinin değerlendirilmesi. Erciyes T⿰р Dergisi, 30(2), 92-99.

Öztürk, G., Çetin, M., Yıldıran, N., Türk, Y. ve Fedai, T. (2012). Hekimlerde tükenmişlik ve iş doyumu düzeyleri. Anatol J Clin Investing, 6(4), 239-245.

Pelit, E. ve Türkmen, F. (2008). Otel işletmeleri işgörenlerinin tükenmişlik düzeyleri: yerli ve yabancı zincir otel işletmeleri işgörenleri üzerinde bir araştırma. Gą̧i Üniversitesi İktisadi ve İdari Bilimler Fakültesi Dergisi, 10(1), 117 139.

Ramires, A., Graham, J., Richards, M. vd. (1996). Mental health of hospital consultanst: The effect of stress and satisfaction at work. Lancet, 347, 724-728.

Rodoplu, D. (2006). Bilgi yönetim projeleri uygulamalarndaki teknolöik değz̧şimlere karşı çalsşan direncinin ölçümü kocaeli üniversitesi t九p fakülttesi ve anadolu sağglk merkę̧inde bir uygulama (Yayınlanmamış Doktora Tezi). Kocaeli Üniversitesi, Sosyal Bilimler Enstitüsü, Kocaeli.

Sağlam, A. ve Bal, E. (2008). Tükenmişlik kavramı: Birey ve örgütler açısından önemi. celal bayar üniversitesi. İIBF Yönetim ve Ekonomi Dergisi, 15(3), 131-148.

Sayıl, I., Haran, S., Ölmez, Ş. ve Özgüven, H. (1997). Ankara üniversitesi hastanelerinde çalışan doktor ve hemşirelerin tükenmişlik düzeyleri. Kriz Dergisi, 5(2), 71-77. doi:10.1501/Kriz_0000000009

Schweitzer, B. (1994). Stress and burnout in junior doctors. South African Medical Journal, 84(6), 352-354.

Süloğlu, A. (2009). Diyaliz merkezlerinde çalışan doktor ve hemşirelerde. dr. sadi konuk eğitim ve araştırma hastanesi (Aile Hekimliği Yayınlanmamış Uzmanlık Tezi). İstanbul.

Tuğrul, B. ve Çelik, E. (2002). Normal çocuklarla çalışan anaokulu öğretmenlerinde tükenmişlik. Pamukkale Üniversitesi Ë̆itim Fakültesi Dergisi, 2(12), 1-11.

WHO. (2002). European Forum of Medical Associations and the WHO. 08 05, 2019 tarihinde www.cmpe.eu: http://www.cpme.eu/european_forum_of_medical_associations_and_the_who adresinden alınd1

Yaman, H. ve Urgan, M. (2002). Tükenmişlik: Aile hekimliği asistan hekimleri. Türk Psikoloji Dergisi, 17, 37-44.

Yavuzyılmaz, A., Topbaş, M., Çan, G. ve Özgün, Ş. (2007). Trabzon il merkezindeki sağlık ocakları çalışanlarında tükenmişlik sendromu ile iş doyumu düzeyleri ve ilişkili faktörler. TSK Koruyucu Hekimlik Bülteni, 6(1), 41-50.

\section{EXTENDED ABSTRACT}

The problems that the individual faces in every moment of his/her life by gaining momentum with the effect of changing and developing technology can disrupt the individual's balance in every sense. The individual faces difficulties primarily in his / her daily life due to reasons such as differentiation in his / her responsibilities in the business life and increase in the workload. Employees, who are under extreme stress in the face of these difficulties, learn to combat stress with the aim of solving this problem or face the exhaustion caused by stress by succumbing to stress. The state of extinction is seen especially in professional fields, which provide services directly to people and where the quality of the work is directly proportional to human factors. Burnout is a situation that adversely affects those struggling to adapt to today's world and all occupational group workers. The individual who tries to adapt to today's modernizing society is likely to experience burnout in certain proportions regardless of demographic characteristics and this possibility is increasing rapidly.

As it is seen from the researches, the feeling of burnout causes the performance of the individual, professional and job satisfaction, high quality service delivery and away from work and this feeling is especially prevalent among healthcare workers, tourism professionals, bankers, teachers and similar occupational groups. For this reason, health professionals were selected as the occupational group that constitutes the demographic structure of the study. Due to the nature of their working environment, health staffs are exposed to more occupational burnout than other groups because they have to provide continuous and quality service to people in need of assistance. Considering that health staffs are at risk in terms of occupational burnout, possible negativities that may occur were evaluated, measuring burnout levels and determining whether burnout levels made demographic differences.

Maslach's ideas are widely accepted in research on burnout. Masclach; As a result of these studies, burnout is defined as a reaction to the stresses and chronicity that cause deterioration of the individual's balance in working life. The concept of burnout was updated by Maslach and colleagues in their following dimensional and functional studies and it was dealt with as syndrome a decrease in the personal success of individuals working at the same capacity, a syndrome that emerges as emotional burnout and loss of self ". Maslach, in simple terms, expressed burnout as personal and emotional stress that occurs in the workplace 
and becomes chronic ". Although different expressions of concept have been used since 1974, the burnout model of Maslach and Jackson (1981) is generally accepted. This model consists of three subfactors; decreased emotional exhaustion, increased depersonalization and lack of personal accomplishment. The "Maslach burnout scale developed by Christina Maslach is used throughout the researches. The scale included the dimensions of emotional exhaustion, depersonalization, and diminished personal achievement. In this context, the concept of burnout as a syndrome with three sub-dimensions should be evaluated in a complex structure. In Maslach burnout syndrome, an individual feels cold, indifferent or even inhumane attitudes towards the people and the profession he / she provides with the feeling of diminishing energy and depletion of his emotional resources. Evaluating the individual within the framework of this attitude, Maslach made evaluations about the sub-dimensions of emotional exhaustion, depersonalization and lack of personal accomplishment with the model. Since burnout is a condition with different symptoms and levels from person to person, the causes of burnout need to be addressed separately. However, the causes of burnout were collected under two main headings as individual and organizational. Personality characteristics and factors related to individual's attitude towards work; gender, marital status, number of children, age, educational status, working time, position, etc. situations are considered as individual characteristics. On the other hand; It is possible to list the conditions such as working environment, working system, organizational structure, characteristics of work, quality of work, weight of the work, management style, reward-punishment applications and internal justice as organizational features. In general terms, due to the fact that the situations in the individual and organizational structure vary for each individual and affect the individual at different levels, the determination of the situation needs to be handled in many ways. Burnout is a frequently encountered phenomenon in the workplace with the causes and symptoms. It is important to determine the personal variables and organizational factors that are important for the methods used in the determination of burnout. Individuals who share the same working environment may experience different levels of burnout. In order to determine the causes and levels of burnout of these individuals, attention should be paid to personal variables. It is important to observe the effect of a working environment which is a source of stress and social negativity on individuals with different demographic structure. The relationship between burnout level and demographic characteristics can be determined in this way. People are at the heart of health care providers' service and they are in constant communication with other people of different demographics at every moment of human work. This situation leads to a negative situation caused by pressure and stress on the employee, exhaustion of energy and burnout as an end point. All the negativities experienced by health care workers in business life affect the other people that they provide health services badly before him and the institution he is in charge. In this study, the burnout levels of health staffs working in public hospitals were analyzed in this study.

This study was conducted on staff working in five public hospitals in Samsun in March 2019. In the survey, 449 of the health care workers to whom the form was distributed provided feedback. In the study, the demographic characteristics of the health care workers in the sample group and the characteristics of the health institutions they work for were given as frequency and percentage distributions.

As a result of the findings obtained from the research, it was found that the factors of gender, number of children and employment type did not affect the burnout levels of the health staffs participating in the survey. On the other hand, age, education level, marital status, total term of duty in the profession, total term of duty in the institution and position in the institution were found to affect the burnout level of the employees.

When the effect of individual variables on burnout level is evaluated, it is seen that burnout syndrome is present among the employees and it is moderate. At the most fundamental point, it is necessary to take the necessary steps to create the feeling that employees are seen as a value in order to reduce the burnout level to a minimum level, and to believe that each employee is a part of the team in providing health services and that they are accepted as values for the institution and the society.

As a result; health staffs work in a high-tempo environment in which they have to communicate intensively with their colleagues and patients they serve. In order to expect a dedicated and high-quality health service from healthcare workers, a working environment consisting of emotionally comfortable individuals with high levels of personal achievement and responsiveness to the tasks and individuals to which they are responsible is required. Therefore, it is important to examine the occupational burnout level of healthcare workers in certain periods both individually and organizationally. 